Lucyna Kopciewicz

Uniwersytet Gdański

\title{
Pedagogika krytyczna dziś?
}

Moja odpowiedź na pytanie o to, czym jest pedagogika krytyczna w dzisiejszej Polsce po dwudziestu latach ustrojowej transformacji, nie wpisuje się w porządek stwierdzeń typu "nie ma jej wcale”, , ,jest w kiepskiej kondycji”. Diagnoza ta jest oczywiście trafna, ale dotyczy "pedagogiki dziś", nie tylko pedagogiki krytycznej. Myśląc o „nieobecności pedagogiki” mam bowiem na myśli jej marginalne miejsca w uniwersytecie i słabą, niemą pozycję w przestrzeni publicznej.

Pytanie o pedagogikę krytyczną dziś w Polsce wiąże się z pytaniem o to, czym była ona kiedyś dla mnie, dla moich koleżanek i kolegów studiujących pedagogikę w Uniwersytecie Gdańskim. Uczenie się pedagogiki krytycznej w pierwszej połowie lat 90. XX wieku było fascynujące z uwagi na jej odmienność od skompromitowanej pedagogiki socjalistycznej oraz wyraźny dystans względem „powinnościowej" pedagogiki inspirowanej katalogiem wartości konserwatywnych. Pedagogika krytyczna była wyrazista i inna. Oferowała dostęp do innego instrumentarium (teorii, pojęć, sposobów analizy) i otwierała nowe możliwości badań: relacji władzy, polityczności kultury, siły pozycji podmiotów w istniejącym porządku społecznym, procesów wytwarzania i narzucania pewnych wersji kulturowego ładu kosztem innych, czy wreszcie - nierównych stosunków sił między grupami społecznymi utrwalanych przez szkołę.

Pedagogika krytyczna była dla nas wszystkich - wówczas studiujących pedagogikę - bezapelacyjnie fascynująca i mocna. Dyskutowaliśmy o niej na zajęciach i na studenckich imprezach. Żaden inny nurt nie był wart większego zainteresowania. Pedagogika personalistyczna wydawała się nam podejrzana i fałszywa, liczne nurty liberalne - były akceptowalne, lecz nieporywające $\mathrm{w}$ porównywalnym do pedagogiki krytycznej stopniu. Kilka osób związanych z katolickim ruchem oazowym odnosiło się do niej z większą nieufnością (za „skażenie lewicowością"). Niemniej jednak opuszczając mury uczelni mieliśmy przekonanie, że wśród licznych nurtów, z których można czerpać inspirację, jest ten ,jeden ważniejszy".

Z dzisiejszej perspektywy zdajemy sobie sprawę, że pedagogika krytyczna w Polsce była odczytywana bardzo bezpiecznie. Do dziś wiele problemów nie doczekało się poważniejszego, badawczego opracowania. Mam na myśli wachlarz 
tematów radykalnie problematyzujących grupę zagadnień wiążących się z normalizacją, hierarchizacją i polityką głosu mniejszości. Środowisko pedagogiczne, w tym pedagogów krytycznych, jest bardzo powściągliwe w publicznym wspieraniu tego głosu. Mniejszości chyba nie mogą na nas liczyć.

Inną istotną kwestią, którą przyjęliśmy jako pewnik, jest to, że pedagogika krytyczna dotyczy „kulturowych innych”, słabszych grup społecznych, marginalizowanych i skazanych na milczenie w socjalizacyjnym treningu szkolnym. Niemniej jednak polska pedagogika krytyczna zadowala się tworzeniem wiedzy o owych "innych" (o ich nierówności, o warunkach społecznych, w których oni żyją), a w mniejszej mierze - wiedzy zaangażowanej, tworzonej w ich interesie. Efektem tej pracy są liczne, błyskotliwe studia empiryczne, które niewątpliwie ułatwiają akademicki awans, ale niekoniecznie służą emancypacji tych, których doświadczenia biograficzne stały się cennym "materiałem empirycznym”.

Kolejnym istotnym problemem związanym ze współczesną pedagogiką krytyczną jest "znaczące przeoczenie" jednego z ważniejszych wątków badawczych, jakim jest analiza relacji władzy w samej pedagogice. Szkoda, że nie badamy tego, czym są i jakie są relacje władzy w akademickiej pedagogice; tego, w jaki sposób "mamy władzę" (jak jej używamy), ale i tego, jak owa władza "ma” nas, ograniczając naszą badawczą wyobraźnię, czasami zmuszając do milczenia i odbierając cywilną odwagę. Badanie relacji władzy mogłoby - jak sądzę - przynieść wiedzę o pokładach protekcjonalizmu i licznych formach (sytuacjach), w których ów protekcjonalizm się pojawia: nauk ścisłych dyscyplinujących humanistyczne, pracowników samodzielnych przywołujących do porządku niesamodzielnych, badaczy szkoły względem nauczycieli, pracowników akademickich względem studentów, hermetycznego świata uczelni wyższej względem „świata praktyki” i wielu innych podziałów "my" - "oni".

Badanie relacji władzy przyniosłoby wiedzę na temat licznych postaci działania cenzury i autocenzury praktykowanej w akademickiej codzienności strachu, asekuranctwa, "gryzienia się w język", przekonania "to i tak nic nie zmieni” - w imię jakiegoś „wyższego dobra” lub własnego spokoju. Owa cenzura de facto krępuje gwarantowaną konstytucyjnie wolność badań naukowych (w obawie, że "taki" temat nie przejdzie ze względów światopoglądowych), zabija odwagę cywilną i socjalizuje do pozorowania układności i grzeczności w zhierarchizowanych akademickich relacjach.

Badanie relacji władzy, na co wskazywał choćby Pierre Bourdieu, mogłoby przynieść wiedzę na temat możliwości i ograniczeń realizacji naukowego libido dominandi w pedagogicznym polu wiedzy i władzy. Mam tu na myśli codzienne sytuacje, w których dochodzi do, z pozoru drobnych, aczkolwiek dojmujących narcystycznych zranień: niedowartościowania, pomijania, odrzucania, niedostrzegania. Innymi słowy, wytwarzania czyjejś nieważności - braku znaczenia. Takie działanie rozproszonej, dyskryminującej władzy opisano w wielu studiach poświęconych problematyce blokad zawodowego awansu jednostek wywodzących się ze słabszych czy opresjonowanych grup społecznych. Zatem w miejsce 
odmowy dostępu pojawia się strategia "niedostrzegania”, w miejsce działania zakazów i wykluczeń - lekceważenie.

Konfrontacja z mechanizmami wytwarzania braku znaczenia rodzi frustrację, agresję lub poczucie niemocy („nienadawania się"). Analizując liczne sytuacje odczuwania frustracji, agresji, zazdrości czy niemocy (szybki awans naukowy młodszego kolegi, wyższe zarobki, liczniejsze publikacje, mocniejsza pozycja i siła przebicia, inne, zwłaszcza filozoficzne, zaplecze teoretyczne), staje się możliwe dotarcie do sposobów działania współczesnej władzy. Warto też przyjrzeć się zjawisku „zdobywania przewagi", strategiom umacniania się jednostek i grup w pedagogicznym polu wiedzy i władzy. Jakie drogi i strategie wiodą do tego celu? Moją intencją nie jest cyniczny instruktaż sprawnego poruszania się w pedagogicznym polu w jego lokalności (identyfikacja dróg szybkiego awansu, właściwych tematów badawczych czy zdobywania władzy), ale chęć poznania określonych mechanizmów $\mathrm{w}$ celu poddania ich - $\mathrm{w}$ miarę możliwości - kontroli. Dokładniejsze przyjrzenie się sobie w sytuacjach niemocy, frustracji, ale też sytuacjach sprawstwa ułatwia odpowiedź na pytania o to, kim jesteśmy i czego chcemy. Ta wiedza może mieć również charakter porządkujący nasze relacje z podmiotami usytuowanymi poza światem akademickiej pedagogiki. Jakiego języka potrzebujemy, by zakomunikować naszą obecność, by odzyskać głos. Jakim językiem zamierzamy komunikować się ze środowiskiem nauczycielskim, związków zawodowych, organizacji pozarządowych, z mediami? Czy efekty naszej pracy badawczej mają osiągać wyżyny wyrafinowania teoretycznego (i niekiedy granic komunikowalności), by sprostać recenzenckim kryteriom dobrej pracy w związku z kolejnym stopniem naukowego awansu, czy raczej powinniśmy dbać o to, by efekty naszych prac czyniły nas partnerami do rozmowy (partnerami, którzy mają coś sensownego do powiedzenia i potrafią o tym mówić w nieakademickich warunkach)?

Akademickie libido dominandi jest dziś dodatkowo wystawione na ciężką próbę - doświadczenie prekaryzacji pracy w uniwersytecie (brak bezpieczeństwa zatrudnienia i jego ciągłości), co niewątpliwie wzmacnia "wsobność" środowiska pedagogicznego (nastawienie na awans) i brak zainteresowania tym, co dzieje się "po sąsiedzku”. Rodzi to kolejne "narcystyczne urazy” (choćby środowiska doktoranckiego), że uniwersytet jest „ślepy jak kret” $i$ „nie widzi”, że oni (doktoranci) są prawdziwymi depozytariuszami krytycznego ducha pedagogiki, którego przenieśli poza mury akademii i wynieśli na takie wyżyny, jakich istnienia akademicy nawet nie przeczuwają ${ }^{1}$. Pomijając to, że uniwersytet $w$ tej konkretnej wypowiedzi zyskał atrybuty wielkiego patrzącego, który powinien widzieć i doceniać, warto odnotować również splot "ambiwalentnych doznań", dobrze opisanych na gruncie studiów postkolonialnych - pogardy względem konserwatywnej, skostniałej instytucji, która wyklucza i jednocześnie marzenia o włączeniu - o znalezieniu się w jej murach (na etacie, choćby na czas określony).

\footnotetext{
1 Wpisy z Facebooka - komentarze po konferencji Pedagogika krytyczna dziś.
} 
Pedagogika krytyczna dziś jest pedagogiką czasu kryzysu. A ten czas niewątpliwie sprzyja społecznemu ruchowi w lewą stronę, w kierunku etyki troski, odbudowy poczucia wspólnotowości i solidarności. Oby nie był to dla nas czas stracony. 